\title{
Ecthyma gangrenosum due to Pseudomonas aeruginosa sepsis as initial manifestation of X-linked agammaglobulinemia: a case report
}

\author{
Haixia Huang ${ }^{1}$, Ke Bai ${ }^{1}$, Yueqiang Fu' ${ }^{1}$, Jin Yan ${ }^{2}$ and Jing $\mathrm{Li}^{1 *}$
}

\begin{abstract}
Background: X-linked agammaglobulinemia (XLA, OMIM\#300,300), caused by mutations in the Bruton tyrosine kinase $(B T K)$ gene, is a rare monogenic inheritable immunodeficiency disorder. Ecthyma gangrenosum is a cutaneous lesion caused by Pseudomonas aeruginosa that typically occurs in patients with XLA and other immunodeficiencies.

Case presentation: We report the case of a 20-month-old boy who presented with fever, vomiting, diarrhea, and ecthyma gangrenosum. Blood, stool, and skin lesion culture samples were positive for $P$. aeruginosa. A diagnosis of XLA was established, and the c.262G > T mutation in exon 4 of BTK was identified with Sanger sequencing. Symptoms improved following treatment with antibiotics and immunoglobulin infusion.

Conclusions: Primary immunodeficiency (i.e., XLA) should be suspected in male infants with $P$. aeruginosa sepsis, highlighting the importance of genetic and immune testing in these patients.
\end{abstract}

Keywords: Pseudomonas aeruginosa, Ecthyma gangrenosum, X-linked agammaglobulinemia, male infants

\section{Background}

$\mathrm{X}$-linked agammaglobulinemia (XLA) is a rare inheritable disease characterized by primary immunodeficiency and caused by monogenic mutations in the Bruton tyrosine kinase $(B T K)$ gene $[1,2]$. The mutations prevent precursor $\mathrm{B}$ cells in the bone marrow from forming mature, circulating B-lymphocytes, which results in clinically undetectable levels of all immunoglobulin isotypes. In human subjects with immunodeficiency, XLA has been associated with opportunistic infection by the gram-negative bacterium Pseudomonas aeruginosa [3].

\footnotetext{
* Correspondence: 400187@hospital.camu.edu.cn

${ }^{1}$ Intensive Care Unit, Key Medical Laboratory of Pediatrics, Key Laboratory of Child Development and Disorders, Chongqing Health Bureau, Ministry of Education, Children's Hospital of Chongqing Medical University, 136\#, Zhong Shan 2nd Rord, Yuzhong District, Chongqing, People's Republic of China Full list of author information is available at the end of the article
}

Ecthyma gangrenosum is a cutaneous lesion caused by $P$. aeruginosa that requires prompt diagnosis and treatment [4]. Here, we report the case of a 20-month-old boy with XLA and ecthyma gangrenosum caused by $P$. aeruginosa as the initial presenting feature. Sanger sequencing revealed a new hemizygous variant of the $\mathrm{X}$ linked BTK gene (c.262G > T in exon 4).

\section{Case presentation}

A 20-month-old boy presented to our institution on April 11, 2018 with a 4-day history of fever reaching $39.5^{\circ} \mathrm{C}$, vomiting, and diarrhea. The parents noted asymmetrical skin lesions on the patient's limbs one day prior to admission. He was previously healthy, and had no known history of drug allergies, recent travel, or family history of immunodeficiency. The patient had received

(c) The Author(s). 2020 Open Access This article is licensed under a Creative Commons Attribution 4.0 International License which permits use, sharing, adaptation, distribution and reproduction in any medium or format, as long as you give appropriate credit to the original author(s) and the source, provide a link to the Creative Commons licence, and indicate if changes were made. The images or other third party material in this article are included in the article's Creative Commons licence, unless indicated otherwise in a credit line to the material. If material is not included in the article's Creative Commons licence and your intended use is not permitted by statutory regulation or exceeds the permitted use, you will need to obtain permission directly from the copyright holder. To view a copy of this licence, visit http://creativecommons.org/licenses/by/4.0/. The Creative Commons Public Domain Dedication waiver (http://creativecommons.org/publicdomain/zero/1.0/) applies to the data made available in this article, unless otherwise stated in a credit line to the data. 

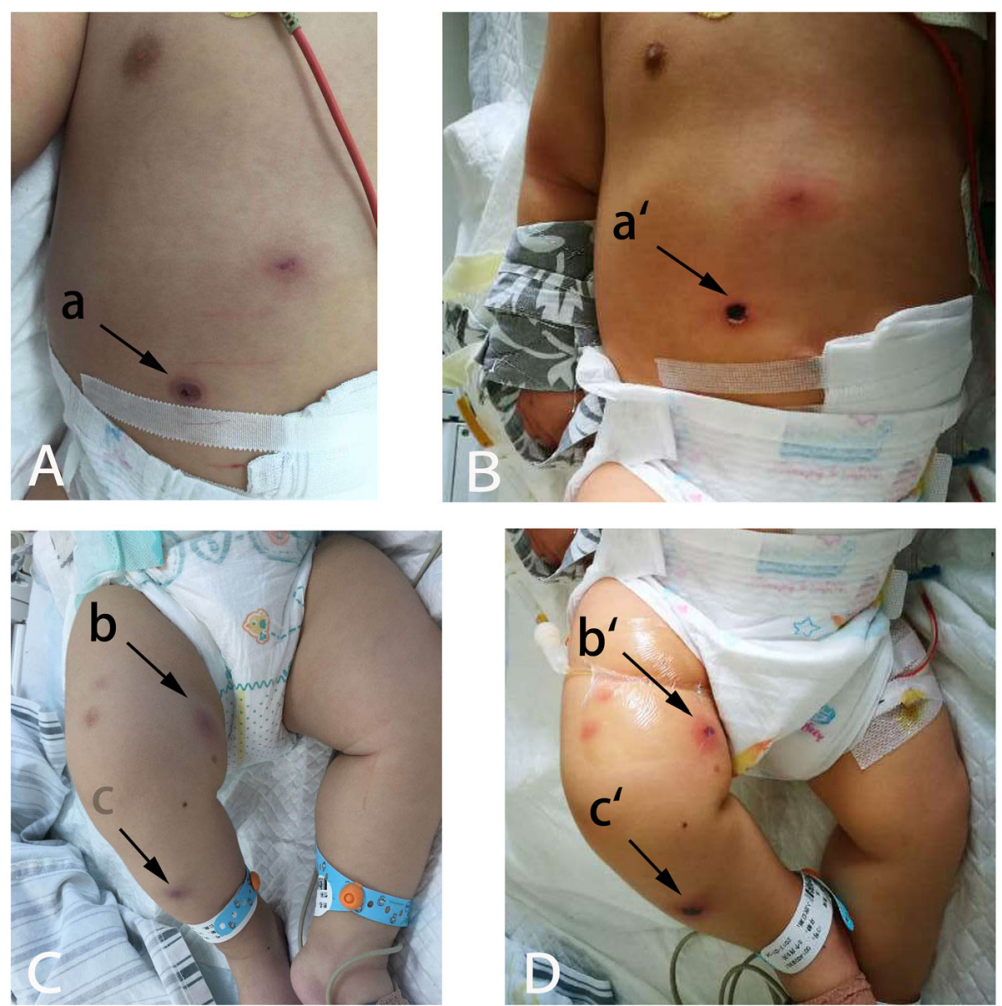

Fig. 1 General appearance of the patient showing multiple purple necrotic lesions. (A) Day 1, ICU: Initial appearance of the abdominal lesions of ecthyma gangrenosum (a). (B) Day 2, ICU: The black central eschar in the lesion was deep seated and large (a'). (C) Day 1, ICU: Initial appearance of the lesions over the right lower leg (b\&c).(D) Day 2, ICU: The erythematous lesions appeared as gangrenous ulcers (b'); The black central eschar was deep seated and large (c')

Table 1 Laboratory data

\begin{tabular}{|c|c|c|c|c|c|c|c|c|c|}
\hline & Day 1 & Day3 & Day 6 & Day 7 & Day 8 & Day 11 & Day 15 & Day 40 & Reference values \\
\hline $\operatorname{WBC}\left(10^{9} / \mathrm{L}\right)$ & 0.26 & 1.11 & 4.1 & 19.44 & 14.93 & 26.18 & 14.67 & 6.27 & $4-10$ \\
\hline Neutrophils $\left(10^{9} / \mathrm{L}\right)$ & 0.05 & 0.46 & 2.17 & 13.61 & 11.65 & 22.51 & 10.71 & 3.14 & $1.8-6.3$ \\
\hline Eosinophils $\left(10^{9} / \mathrm{L}\right)$ & 0.01 & 0.06 & 0.21 & 0.19 & 0.15 & 0.00 & 0.29 & 0.25 & $0.02-0.52$ \\
\hline Lymphocytes $\left(10^{9} / \mathrm{L}\right)$ & 0.16 & 0.51 & 0.9 & 2.53 & 2.99 & 2.62 & 3.08 & 2.7 & $1.1-3.2$ \\
\hline Monocytes $\left(10^{9} / \mathrm{L}\right)$ & 0.04 & 0.09 & 0.21 & 0.78 & 0.15 & 0.52 & 0.59 & 0.19 & $0.1-0.6$ \\
\hline CRP (mg/dL) & 86 & 60 & 27 & 59 & 83 & 57 & 32 & $<8$ & $<8.0$ \\
\hline Procalcitonin (ng/mL) & 49.04 & $>100$ & 70.65 & 42.91 & 23.09 & 1.421 & 0.544 & 0.044 & $<2.0$ \\
\hline $\mathrm{K}^{+}(\mathrm{mmol} / \mathrm{L})$ & 3.67 & 3.17 & 3.45 & & & 3.41 & 4.36 & 4.18 & $3.5-5.5$ \\
\hline $\mathrm{Na}^{+}(\mathrm{mmol} / \mathrm{L})$ & 133.3 & 156.1 & 138.2 & & & 139.3 & 137.9 & 141.8 & 132-149 \\
\hline $\mathrm{Cl}^{-}(\mathrm{mmol} / \mathrm{L})$ & 103.3 & 97.6 & 90.6 & & & 101.4 & 104.5 & 102.3 & $97-111$ \\
\hline Total $\mathrm{Ca}^{2+}(\mathrm{mmol} / \mathrm{L})$ & 2.15 & 2.64 & 0.85 & & & 2.24 & 2.46 & 2.47 & $2.2-3.0$ \\
\hline $\mathrm{Mg}^{2+}(\mathrm{mmol} / \mathrm{L})$ & 0.83 & 0.77 & & & & 0.75 & 0.75 & 0.93 & $0.53-1.11$ \\
\hline $\lg G(g / L)$ & & 4.94 & & 10.5 & & & & & $2.86-16.8$ \\
\hline $\lg A(g / L)$ & & 0.068 & & $<0.067$ & & & & & $0.19-1.75$ \\
\hline $\lg M(g / L)$ & & 0.185 & & 0.12 & & & & & $0.43-1.63$ \\
\hline Plasma albumin (g/L) & & 19 & & 37.3 & & & & & $37-52$ \\
\hline T lymphocytes (\%) & & 96.48 & & & & & & & $39-73$ \\
\hline B lymphocytes (\%) & & 0.1 & & & & & & & $7-41$ \\
\hline
\end{tabular}


age-appropriate live attenuated vaccines and showed no symptoms of discomfort.

On admission, physical examination showed the patient had met typical developmental milestones. He was lethargic and febrile $\left(39.1^{\circ} \mathrm{C}\right)$; pulse rate was $155 /$ min, respiratory rate was $56 / \mathrm{min}$, and blood pressure was normal. The patient had a bulging anterior fontanelle, pupils were equal and reactive, and there was no abnormality in limb strength. Apparent subcostal retraction was observed. Arterial oxygen saturation $\left(\mathrm{SaO}_{2}\right)$ was $100 \%$. Fine inspiratory rales were present on auscultation. Multiple purple necrotic lesions were visible on the abdomen and the right leg (Fig. 1). Laboratory tests (Table 1) revealed low peripheral white blood cell count $0.26 \times 10^{9} / \mathrm{L}$ (normal reference values: $4-10 \times 10^{9} / \mathrm{L}$ ) with neutropenia (neutrophils, $0.05 \times 10^{9} / \mathrm{L}$; normal reference values: $1.8-6.3 \times 10^{9} / \mathrm{L}$ ), eosinophils $0.01 \times 10^{9} / \mathrm{L}$ (normal reference values: $0.02-0.52 \times 10^{9} / \mathrm{L}$ ), lymphocytes $0.16 \times 10^{9} / \mathrm{L}$ (normal reference values: $\left.1.1-3.2 \times 10^{9} / \mathrm{L}\right)$, monocytes $0.04 \times$ $10^{9} / \mathrm{L}$ (normal reference values: $0.1-0.6 \times 10^{9} / \mathrm{L}$ ), and elevations in C-reactive protein (CRP, $86 \mathrm{mg} / \mathrm{dL}$; normal reference value: $<8.0$ ) and procalcitonin (49.04 ng/mL; normal reference value: $<2.0$ ).
Ecthyma gangrenosum due to $P$. aeruginosa sepsis was suspected. Intravenous ceftazidime $(50 \mathrm{mg} / \mathrm{kg}$, twice a day) was initiated. Four hours after admission, the patient experienced a seizure that was controlled by phenobarbital $\left(5 \mathrm{mg} / \mathrm{kg}\right.$, iv). Two hours later, $\mathrm{SaO}_{2}$ decreased to $86 \%$. The patient was transferred to the pediatric intensive care unit (ICU) for mechanical ventilation. One hour after ICU admission, blood pressure was $50 / 30 \mathrm{mmHg}$ and heart rate was $185 / \mathrm{min}$. The patient received fluid resuscitation and inotropic support. Urine output was $<0.5 \mathrm{~mL} / \mathrm{kg} / \mathrm{h}$ during the 12 hours following ICU admission, and plasma albumin was $19 \mathrm{~g} / \mathrm{L}$ (normal reference values: $37-52 \mathrm{~g} / \mathrm{L}$ ). Capillary leakage syndrome was considered. Colloids, including albumin, were given intravenously and continuous renal replacement therapy was initiated, but high fever persisted with repeated seizures. Blood, skin lesion, and stool culture samples taken on admission and returned on Day 3 of admission showed $P$. aeruginosa was found in all specimens and was sensitive to meropenem and levofloxacin but resistant to ceftazidime and pieracillin. Ceftazidime was replaced with meropenem (40 mg/kg, q8h) and levofloxacin $(5 \mathrm{mg} / \mathrm{kg}, \mathrm{q} 12 \mathrm{~h})$. On Day 6 of admission, white blood cell count recovered to $4.1 \times 10^{9} / \mathrm{L}$ and CRP
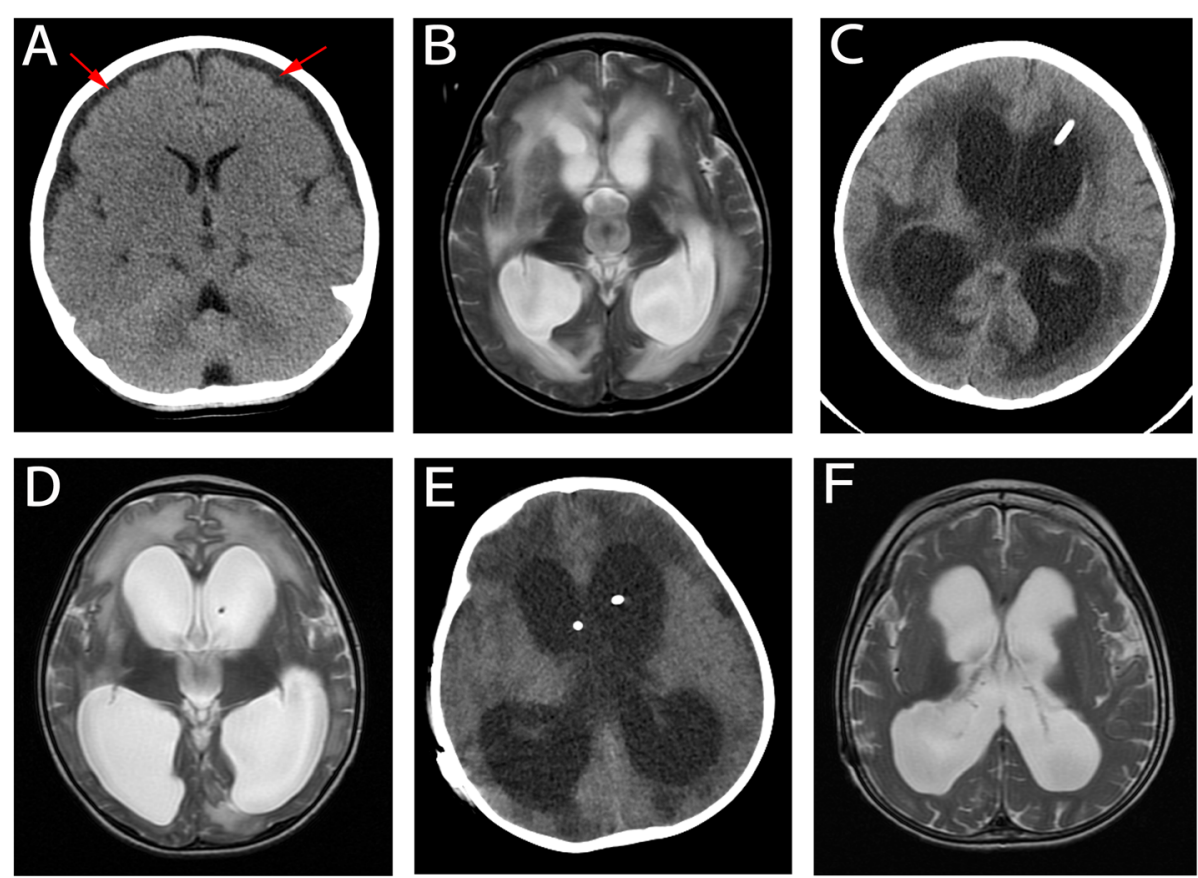

Fig. 2 Serial $C T$ and MRI images showing changes in the brain. a Day 19 of admission: Lateralcranial CT showing diffuse brain edema, hypodensity of the brain parenchyma, and subdural effusion in the bilateral frontal area (red arrow). b Day 25 of admission (one day before Ommaya reservoir implantation): Lateral T2-weighted MRI showing enlarged lateral ventricles and hydrops with peripheral white matter edema. c Day 27 of admission (one day after Ommaya reservoir implantation): Lateral cranial CT showing the drainage tube in the anterior horn of the left lateral ventricle. $\mathbf{d}$ Day 70 of admission (one day before ventriculoperitoneal shunt): Lateral T2-weighted MRI showing hydrocephalus in the ventricles was not obviously aggravated. e Day 72 of admission (one day after ventriculoperitoneal shunt): Lateral cranial CT showing the drainage tube in the lateral ventricle. e 20 months after discharge: Lateral T2-weighted MRI showing less hydrocephalus and improved interstitial cerebral edema 
was $27 \mathrm{mg} / \mathrm{dL}$, but enterococcus was found in the cerebrospinal fluid. Meropenem and levofloxacin were replaced with vancomycin $(15 \mathrm{mg} / \mathrm{kg}$, q6h) combined with meropenem $(40 \mathrm{mg} / \mathrm{kg}, \mathrm{q} 8 \mathrm{~h}$ ). On Day 8 of admission, the patient's body temperature returned to normal. On Day 9 of admission, a cranial computed tomography (CT) scan showed diffuse brain edema (Fig. 2a). Cerebrospinal fluid (CSF) examination revealed protein $5.68 \mathrm{~g} / \mathrm{L}$, glucose $2.62 \mathrm{mmol} / \mathrm{L}$ (blood glucose, $7.0 \mathrm{mmol}$ /L), total cell numbers $1273^{*} 10^{\wedge} 6 / \mathrm{L}$, nucleated cells $1238^{*} 10^{\wedge} 6 / \mathrm{L}$, multinucleated cells $74 \%$, and mononuclear cells $26 \%$. Purulent meningitis was considered, and ceftazidime treatment was continued. Intravenous mannitol ( $5 \mathrm{ml} / \mathrm{kg}$ body weight, $\mathrm{q} 4 \mathrm{~h}$ ) and oxcarbazepine (5 $\mathrm{mg} / \mathrm{kg}$ body weight, $\mathrm{q} 12 \mathrm{~h}$ ) were given to control intracranial edema and seizures. Over the subsequent three days, the dose of oxcarbazepine was gradually increased to a maximum of $20 \mathrm{mg} / \mathrm{kg}$ body weight. The patient was taken off the ventilator. On Day 11 of admission, the patient experienced fever and diarrhea, and $P$. aeruginosa was resistant to meropenem but sensitive to levofloxacin; therefore, meropenem was replaced with levofloxacin. On Day 13 of admission, the patient was transferred back to the general ward; his state of consciousness was evaluated as a light coma. On Day 15 of admission, the patient's body temperature returned to normal, and his diarrhea was greatly alleviated.

An immune panel was ordered (Table 1), which showed: plasma IgG $4.94 \mathrm{~g} / \mathrm{L}$ (normal reference: $2.86-$ $16.8 \mathrm{~g} / \mathrm{L}$ ), IgA $0.068 \mathrm{~g} / \mathrm{L}$ (normal reference: $0.19-1.75 \mathrm{~g} /$
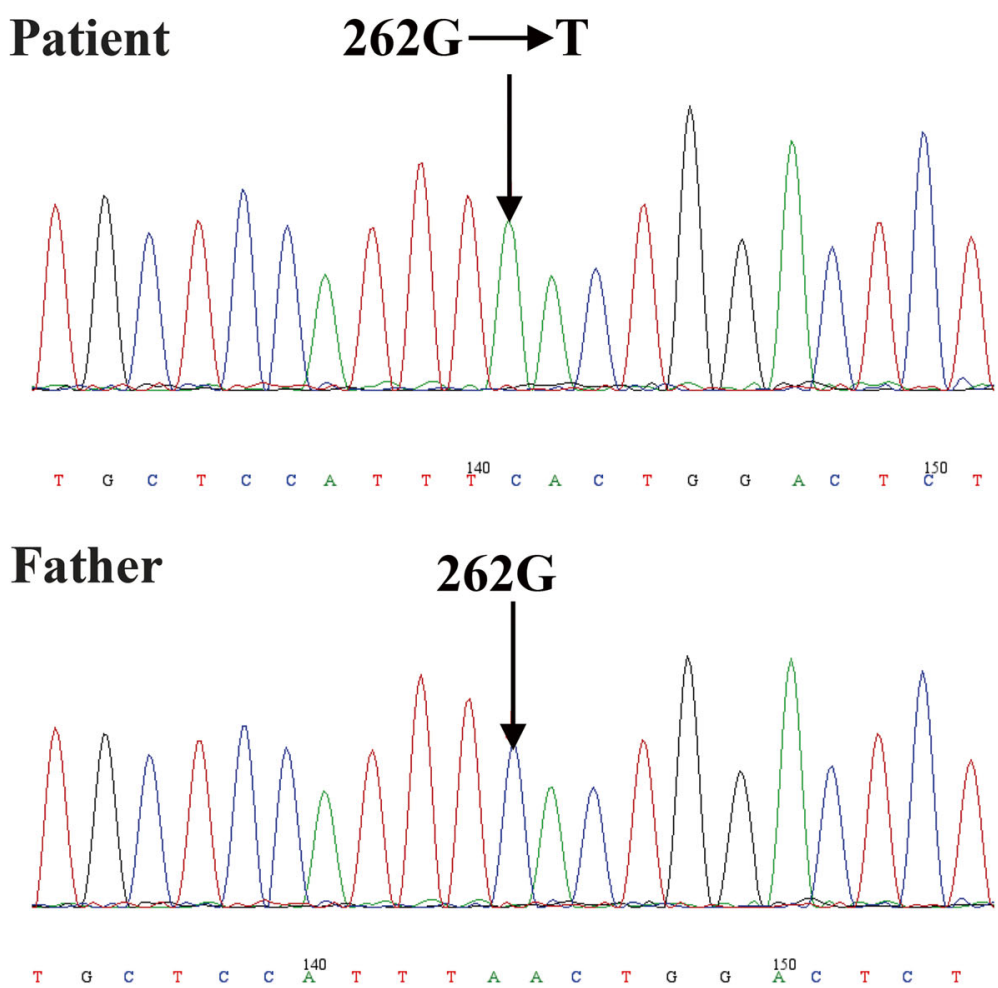

\section{Mother 262G/T Heterozygote}

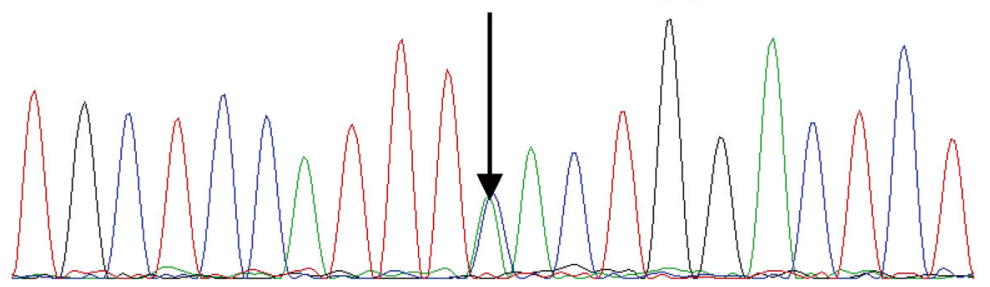

Fig. 3 Results of Sanger sequencing for blood samples from the patient (upper panel) and parents (bottom panel) 
$\mathrm{L}$ ), and IgM $0.185 \mathrm{~g} / \mathrm{L}$ (normal reference: 0.43-1.63 g/L). The percentage of $\mathrm{T}$ lymphocytes $\left(\mathrm{CD}^{+}\right)$was $96.48 \%$ (normal reference: 39\%-73\%) and B-cells $\left(\mathrm{CD}^{-} \mathrm{CD} 19^{+}\right.$) were absent $(0.1 \%$, normal reference: $7 \%-41 \%)$ in peripheral blood. Second generation sequencing of immunerelated genes was performed to screen possible mutations; subsequently, Sanger sequencing was applied to verify possible mutations. A hemizygous mutation (c.262G > T) in exon 4 of the X-linked BTK gene was found (Fig. 3, upper panel). The patient was diagnosed with XLA, and the mother was identified as a carrier (Fig. 3, bottom panel).

On Day 25 of admission, the patient was moderately comatose, spontaneous movements were reduced, and his response to stimulus or pain was poor. Cranial magnetic resonance imaging (MRI) showed severe hydrocephalus, which was managed by Ommaya reservoir implantation (Fig. 2b-c). On Day 70 of admission, repeat cranial MRI showed no significant increase in hydrocephalus, and CSF examination was normal; therefore, a ventriculoperitoneal shunt was inserted (Fig. 2d-e). On Day 29 of admission, the patient's left elbow became swollen and movement was restricted. X-ray showed soft tissue swelling around the elbow (Fig. 4A). Pyogenic osteomyelitis was considered, and antibiotics (levofloxacin and vancomycin) were continued. On Day 47 of admission, MRI showed bone destruction in the left elbow joint and adjacent soft tissue swelling (Fig. 4B), supporting the diagnosis of pyogenic osteomyelitis. The left elbow remained swollen, but some movement was restored. Repeat culture of blood, stool, and CSF specimens revealed negative results. Considering the condition of the patient, antibiotics were changed to intravenous piperacillin-tazobactam $(4: 1,50 \mathrm{mg} / \mathrm{kg}$, q8h) for 3 weeks.

On Day 129 of admission, repeat MRI indicated that hydrocephalus was stable, and the child was discharged from hospital. Monthly intravenous immunoglobulin was prescribed. At the last follow-up on February 10, 2020, the patient remained bed-ridden in a semiconscious state, with limited responses to stimuli, increased muscle tone, and a normal swallowing reflex.

\section{Discussion}

In the present case, the patient was diagnosed with suspected XLA based on clinical manifestations and results of laboratory tests that showed a life-threatening bacterial infection and severe immunodeficiency, including a marked reduction in all classes of serum immunoglobulins, reduced numbers of B lymphocytes in the peripheral circulation, and severe neutropenia. A diagnosis of XLA was established after the identification of a novel hemizygous variant of the X-linked BTK gene on Sanger sequencing.

XLA is a pediatric primary immunodeficiency characterized by a history of recurrent bacterial infections [5]. Encapsulated bacteria, particularly Streptococcus pneumoniae, Haemophilus influenza, Staphylococcus aureus, and Pseudonmona sp, are the most common bacteria to cause invasive infections in patients with XLA $[5,6]$. There is no cure for XLA; therefore, early diagnosis and management to prevent and treat infections is essential.

Patients with XLA typically suffer from recurrent gastrointestinal infections and sino-pulmonary infections such as otitis media, sinusitis, bronchitis, and pneumonia [6]. Patients with XLA rarely present with ecthyma
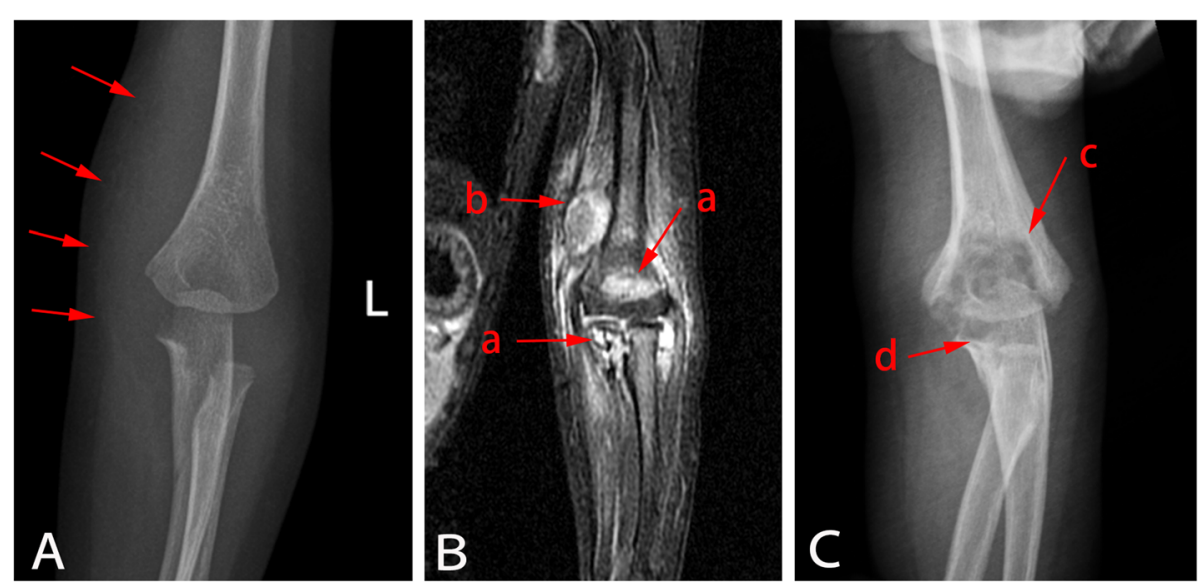

Fig. 4 X-ray and MRI images showing changes around the left elbow. (A) Day 29 of admission: X-ray showing swelling of soft tissue around the left elbow (arrow). (B) Day 47 of admission: Coronal T2-weighted MRI showing patchy hyperintensity in the left humerus and proximal ulna (a) accompanied by soft tissue edema and abscess formation around the elbow joint (b).(C) Day 96 of admission: X-ray showing low-density shadows in the left humerus, suggesting bone destruction (c). Similar less severe changes were observed in the proximal left ulna (d). Soft tissue swelling was reduced 
Table 2 Summary of cases of $P$. aeruginosa sepsis and ecthyma gangrenosum as the initial manifestation in XLA patients

\begin{tabular}{|c|c|c|c|c|c|c|}
\hline Year & Cases No. & Exon/intron & Mutation & Age (mos) & Antibiotics & Ref \\
\hline 2020 & 1 & Exon 4 & c. $262 \mathrm{G}>\mathrm{T}$ & 20 & meropenem/levofloxacin & $\overline{\text { present }}$ \\
\hline 2020 & 2 & Exon 10 & $\mathrm{c} .862 \mathrm{C}>\mathrm{T}$ & 7 & ceftazidime/gentamicin & [17] \\
\hline 2019 & 1 & - & c.1555T p.H519Y & 11 & piperacillin-tazobactam /ciprofloxacin & [16] \\
\hline 2018 & 1 & - & c.726dupT; p.lle243TyrfsTer15 & 19 & meropenem & [15] \\
\hline 2017 & 1 & - & NA & 16 & meropenem/gentamicin & [14] \\
\hline 1996 & 2 & - & NA & 28,24 & $\begin{array}{l}\text { ticarcillin/gentamicin } \\
\text { ticarcillin/gentamicin }\end{array}$ & [13] \\
\hline 1991 & 2 & - & NA & $\begin{array}{l}6 \\
30\end{array}$ & $\begin{array}{l}\text { carbenicillin/tobramycin } \\
\text { ampicillin/piperacillin/amikacin }\end{array}$ & [12] \\
\hline 1963 & 1 & - & NA & 11 & Colomycin & [11] \\
\hline
\end{tabular}

gangrenosum caused by $P$. aeruginosa infection. In the present case, the patient was asymptomatic until 20 months of age, when he presented with $P$. aeruginosa sepsis and ecthyma gangrenosum. $P$. aeruginosa infection has been reported in children with primary immunodeficiency, including Wiskott-Aldrich syndrome, cyclic neutropenia, IRAK-4/MyD-88 deficiency, centromeric region instability, facial anomalies syndrome, and XLA [7-9]. Ecthyma gangrenosum is a key characteristic of $P$. aeruginosa sepsis. Initially it manifests as edematous lesions, then it becomes erythematosus, and finally it evolves into hemorrhagic bullae or gangrenous ulcers with a black central eschar [10].

In 1963, Speirs et al. first described $P$. aeruginosa sepsis and ecthyma gangrenosum as the initial manifestation of XLA [11]. Table 2 summarizes 11 similar cases in the published literature [11-17]. Among these, patients were aged from 6-months to 28-months [11-17]. In only five cases (including the present case), XLA diagnosis was confirmed by sequencing of the $B T K$ gene [15-17]. Except for one report that included twins [16], all identified $B T K$ mutations were novel, suggesting that sequencing the whole $B T K$ gene is more reliable than site specific polymerase chain reaction (PCR) or hybridization to confirm the molecular diagnosis of XLA.

Intravenous immunoglobulin replacement is standard of care for XLA, but antibiotics were administered in all patients with $P$. aeruginosa infection. Notably, meropenem or gentamicin displayed efficacy in most previous reports (7 cases) $[13-15,17]$. The twins with XLA and $P$. aeruginosa infection were initially treated with meropenem [16]; however, antibiotic susceptibility tests of the isolated $P$. aeruginosa strain showed complete resistance; therefore, therapy was changed to piperacillin-tazobactam plus ciprofloxacin. In the present case, although the first antibiotic susceptibility test showed $P$. aeruginosa was sensitive to meropenem, resistance developed, and antibiotic therapy was changed to levofloxacin. These findings confirm that regular monitoring with antibiotic susceptibility tests is essential to determine the effectiveness of antibiotics for $P$. aeruginosa infection in patients with XLA.

\section{Conclusions}

XLA should be considered in previously healthy patients with $P$. aeruginosa sepsis and ecthyma gangrenosum, especially in male infants. Sequencing of the whole BTK gene is required to confirm diagnosis, and regular monitoring with antibiotic susceptibility tests is needed to achieve a satisfactory outcome.

\section{Abbreviations}

XLA: X-linked agammaglobulinemia; BTK: Bruton tyrosine kinase; $\mathrm{SaO}_{2}$ : Oxygen saturation; CRP: C-reactive protein; ICU: Intensive care unit; MRI: Magnetic resonance imaging; CT: Computed tomography; CSF: Cerebrospinal fluid

\section{Acknowledgements}

We thank the family who agreed to share this patient's information.

\section{Authors' contributions}

$H H X, B K, F Y Q, Y J, L$ analyzed and interpreted the data. HHX, LJ. wrote the manuscript. All authors read and approved the final manuscript.

Funding

Not applicable.

Availability of data and materials

All data generated or analyzed during this study are included in this published article.

Ethics approval and consent to participate

Not applicable.

\section{Consent for publication}

Written informed consent was obtained from the patient's parents for publication of this case report.

\section{Competing interests}

The authors declare that they have no competing interests.

\section{Author details}

${ }^{1}$ Intensive Care Unit, Key Medical Laboratory of Pediatrics, Key Laboratory of Child Development and Disorders, Chongqing Health Bureau, Ministry of Education, Children's Hospital of Chongqing Medical University, 136\#, Zhong Shan 2nd Rord, Yuzhong District, Chongqing, People's Republic of China.

${ }^{2}$ Chongqing Key Laboratory of Translational Research for Cancer Metastasis 
and Individualized Treatment, Chongqing University Cancer Hospital, Chongqing, People's Republic of China.

Received: 6 April 2020 Accepted: 19 November 2020

Published online: 01 December 2020

\section{References}

1. Soresina A, Moratto D, Chiarini M, Paolillo C, Baresi G, Focà E, Bezzi M, Baronio B, Giacomelli M, Badolato R. Two X-linked agammaglobulinemia patients develop pneumonia as COVID-19 manifestation but recover. Pediatr Allergy Immunol. 2020;31(5):565-9.

2 Qin X, Jiang LP, Tang XM, Wang M, Liu EM, Zhao XD. Clinical features and mutation analysis of $X$-linked agammaglobulinemia in 20 Chinese patients. World J Pediatrics. 2013;9(3):273-7.

3. Yang MA, Lee J, Choi EH, Lee HJ. Pseudomonas aeruginosa bacteremia in children over ten consecutive years: analysis of clinical characteristics, risk factors of multi-drug resistance and clinical outcomes. J Korean Med Sci. 2011;26(5):612-8

4. Vaiman M, Lazarovitch $\mathrm{T}$, Heller L, Lotan G. Ecthyma gangrenosum and ecthyma-like lesions: review article. Eur J Clin Microbiol Infect Dis. 2015; 34(4):633-9.

5 Lackey AE, Ahmad F. In: StatPearls, editor. X-linked Agammaglobulinemia. Treasure Island: StatPearls Publishing, StatPearls Publishing LLC.; 2020.

6. Suri D, Rawat A, Singh S. X-linked Agammaglobulinemia. Indian J Pediatr. 2016;83(4):331-7.

7. Wong SN, Tam AY, Yung RW, Kwan EY, Tsoi NN. Pseudomonas septicaemia in apparently healthy children. Acta Paediatr Scand. 1991;80(5):515-20.

8. Stergiopoulou T, Walsh TJ, Seghaye MC, Netea MG, Casanova IL, Moutschen M, Picard C. Deficiency of interleukin-1 receptor-associated kinase 4 presenting as fatal Pseudomonas aeruginosa bacteremia in two siblings. Pediatr Infect Dis J. 2015;34(3):299-300.

9 Asgari S, McLaren PJ, Peake J, Wong M, Wong R, Bartha I, Francis JR, Abarca K, Gelderman KA, Agyeman P, et al. Exome Sequencing Reveals Primary Immunodeficiencies in Children with Community-Acquired Pseudomonas aeruginosa Sepsis. Front Immunol. 2016;7:357.

10. Shah M, Crane JS. Ecthyma Gangrenosum. In: StatPearls. edn. Treasure Island (FL): StatPearls Publishing, StatPearls Publishing LLC:; 2020.

11. Speirs CF, Selwyn S, Nicholson DN. Hypogammaglobulinaemia presenting as pseudomonas septicaemia. Lancet. 1963;2(7310):710-2.

12. Nussinovitch M, Frydman M, Cohen HA, Varsano I. Congenital agammaglobulinemia presenting with ecthyma gangrenosum. Acta Paediatr Scand. 1991;80(6-7):732-4

13. Zenone T, Souillet G. X-linked agammaglobulinemia presenting as pseudomonas aeruginosa septicemia. Scand J Infect Dis. 1996;28(4):417-8.

14. Bhardwaj NK, Khera D, Gupta N, Singh K. Disseminated Pseudomonas aeruginosa sepsis as presenting diagnosis of $\mathrm{X}$-linked agammaglobulinaemia in a previously well 16-month-old child. BMJ Case Rep. 2017. p. bcr2017221006

15. Sanford E, Farnaes L, Batalov S, Bainbridge M, Laubach S, Worthen HM, Tokita M, Kingsmore SF, Bradley J. Concomitant diagnosis of immune deficiency and Pseudomonas sepsis in a 19 month old with ecthyma gangrenosum by host whole-genome sequencing. Cold Spring Harb Mol Case Stud. 2018:4(6):a003244.

16 Riccardi N, Rotulo GA, Favilli F, Loy A, Moratto D, Giliani S, Mesini A, Romanini MV, Volpi S, Moscatelli A, et al. Pseudomonas aeruginosa severe skin infection in a toddler with X-linked agammaglobulinemia due to a novel BTK mutation. Le Infezioni Medicina. 2019;27(1):73-6.

17. Lin SC, Chiang BL, Lee YJ, Chang YT, Fang SB. Pseudomonas aeruginosa sepsis presenting as oral ecthyma gangrenosum in identical twins with Bruton tyrosine kinase gene mutation: Two case reports and review of the literature. J Microbiol Immunol Infect. 2020;30103-1(20):S1684-1182.

\section{Publisher's Note}

Springer Nature remains neutral with regard to jurisdictional claims in published maps and institutional affiliations.

Ready to submit your research? Choose BMC and benefit from:

- fast, convenient online submission

- thorough peer review by experienced researchers in your field

- rapid publication on acceptance

- support for research data, including large and complex data types

- gold Open Access which fosters wider collaboration and increased citations

- maximum visibility for your research: over $100 \mathrm{M}$ website views per year

At BMC, research is always in progress.

Learn more biomedcentral.com/submissions 